\title{
Multi-factor analysis and agrolandscape land use design
}

\author{
Olga Marinina ${ }^{1, *}$, Olesya Grigoreva ${ }^{2}$, and Anastasiya Narozhnyaya ${ }^{1}$ \\ ${ }^{1}$ Belgorod State National Research University, 308015 Belgorod, Russia \\ ${ }^{2}$ Department of agricultural complex and environmental reproduction of the Belgorod region, 308000 \\ Belgorod, Russia
}

\begin{abstract}
The aim of the work was to conduct an agro-ecological assessment of agricultural lands, select a typical test area by key indicators, and conduct a comprehensive analysis with the mapping of the utilisation efficiency of this area. The aim of this work was to demonstrate the fundamental possibility of solving socio-economic and environmental problems of the land use in the context of reforming the land and property complex by the example of a specific project. The algorithm of the land management actions for efficient economic use of the territory of the key site has been offered. The proposed measures are based on the organisation of an arable land with the allocation of field, grain-grass and soil-protective crop rotations, grassing-down of spillways, and conservation of a lowproductive arable land, design of a field-protective forest range, determination of the type of use of natural forage lands, allocation of places for the implementation of erosion-hazardous agricultural land afforestation, organisation of a bee park, clumps of broadleaves and microreserves. The prospectivity of transition from a spatial object of lands assessment to their agro-ecological type by means of morphometric analysis of the terrain using GIS-technologies, calculation of territory roughness, determination of the erosion potential of the terrain, and complex integration of the results into the typification of agro-climatic resources has been proved. The prospectivity of use of soil-recovering effects for the development of new models of resource-saving sustainable agriculture has been demonstrated.
\end{abstract}

\section{Introduction}

To optimise the economic use of lands, to form effective land relations, it is necessary to develop ecologically sustainable and soil-protective agricultural landscape systems. Implementation of adaptive landscape cropping systems with application of new technological solutions of land management design allows providing the efficient use of soil fertility resources in agricultural landscapes.

The influence of methods of forming sustainable land use on the economic and sociocultural development of the country and the region is widely studied both in Russia $[1,2]$

\footnotetext{
* Corresponding author: marinina@bsu.edu.ru
} 
and abroad [3, 4, 5]. Economic, organisational, environmental, and social aspects are the indicators of efficient agricultural land turnover $[6,7]$.

Currently, the transformation of territorial planning to ensure the rational use of natural resources follows the path of applying various concepts $[8,9,10]$, but the basin nature management has some significant advantages $[11,12,13]$. Justification of ecologicallyoriented regional development of the area based on the principles of basin nature management implies the division of geosystems according to the basin-based principles. It is attractive because with the automated identification of watersheds, they are an objective and natural basis for solving territorial issues in the area of nature management and in carrying out geo-planning $[14,15])$. Territory planning in terms of such components as the landscape natural basis, the system of population settlement and the economy, enables to single out such components of geo-planning as the formation of the natural framework of the territory safety, demographic and economic geo-planning $[16,17]$ with their subsequent synthesis. Currently, there is a need for an integrated approach to the organisation of conservation efforts in river basins. Herewith, it is advisable to assess any basin and human-induced load within it from a systemic standpoint, without ignoring any of the aspects (water resources and facilities, other landscape components, sources of humaninduced load, etc.) [18].

The problems of soil and water protection and ecological arrangement of watersheds can be successfully solved when developing land use projects using GIS technologies [19, 20]. A whole new basis for the projects of agriculture soil and water protection systems, which use the results of an unbiased agroecological assessment of lands, is provided by GIS technology tools and remote sensing materials. Their combined application enables creating adequate map models of the territory, identify the features of agroecological conditions and carry out landscaping based on new conceptual principles [21, 22].

\section{Materials and Methods}

The key subject of the study is the land of the joint-stock company Druzhba in the Repyakhovskoye rural settlement, Krasnoyaruzhsky region by Belgorod Oblast. As a test area, this territory has typical geomorphological, geological, and climatic features, which are typical for the forest-steppe part of the Belgorod Oblast territory (it occupies $2 / 3$ of the region's territory).

For the agro-ecological assessment of lands and the design of an adaptive landscape farming system, the - GIS product- package ArcInfo and its application ArcGIS which have a basic model of high-level geographical data to provide file sets of spatial information in the form of vector and raster layers, attributive and statistical information, were used.

Terrain conditions determine the formation and spatial redistribution of all components of erosion and slope geosystems. Erosion potential of the terrain as a set of morphological parameters determines the influence of the terrain on erosion processes. The application of GIS-technologies allows for rapid morphometric terrain analysis through an automated analysis of a raster digital elevation model (DEM). The basis for DEM construction was vector layers of contours and elevations «Topo to raster», which had been obtained from topographic maps. To create a DEM, we used a tool with the obligatory designation of belonging to the class of linear objects, which provides information about the location of flows. The size of the output resolution cell was selected $30 \times 30 \mathrm{~m}$. The obtained DEM allows visualising the investigated territory in three-dimensional space.

The slope steepness has been defined by a program module tool «Spatial Analyst». In this case, the output data type «Raster Layer» and additional parameters have been specified «Raster Layer». This tool sets the units of measurement «Degree», «String» as a 
type of measurement data and as «Z-factor» a set of ground units of $\mathrm{X}, \mathrm{Y}$ coordinates in one unit of Z-value of the surface.

Exposure is expressed from 0 to $359.9^{\circ}$, measured clockwise from north. The input resolution cells with zero slope (flat) have been assigned exposure levels equal to 1 . The slope exposures have been determined by the software «Aspect» by module tools «Spatial Analyst». Reclassification of the obtained pattern made it possible to calculate the total statistics of expositional test areas.

In the GIS environment the program module tool «Curvature» has created a slope shape map, the principle of which is to assign each cell of the input surface of the 4th order polynominal. As a result, maps of the «Out plan curve raster» planned and profile curvature have been formed, at the construction «Out profile curve raster» of which, as well as for slope steepness, the cell height factor has been selected « $Z$ _factor» as an additional parameter.

As a main agro-climatic indicator, which determines heat resources and crop demand, the duration of periods and the sum of average daily temperature values above $10 \mathrm{o}$ have been assumed. Taking into account the fact that the Belgorod Oblast is a region with the leading role of crop production in the specialisation of agriculture, S.A. Sapozhnikova's moisture index has been chosen to assess the area's moisture content, as it takes into account precipitation of warm and cold period of the year, which is more in line with the actual regime of water availability and is important for forecasting crop yields. The erosion network density for the northern and southern part of the farm has been calculated by ArcGIS a software tool «Kernel Density». The soil map has been digitised in the software package ArcGIS by the tool «Field Editor». In total, 60 soil varieties and 480 soil contours have been identified on the territory of the farm.

\section{Results and Discussion}

The analysis of geospatial data showed that both $41 \%$ of the territory of the Belgorod Oblast and the territory of the test area are characterised by flat terrain without significant height differences with prevailing slopes with a steepness of $1-3^{\circ}$, and uniform distribution of slopes along the exposure. The distinctive feature of this area is almost complete absence of chalk-marlaceous rocks on the slopes of gullies and river valleys. One of the topical environmental problems of land use, just like in the whole Belgorod Oblast, is the intensive erosive dissection of the area. In terms of the density of erosive dissection of the terrain, the Belgorod Oblast ranks first among the regions of the Central Black Earth Region. For 74\% of the Oblast land area, this indicator corresponds to the average degree of erosion dissection. The terrain of the test area is characterised by the smoothed forms of watersheds; there are mainly narrow gullies, slopes of which are crossed by numerous water galls. Erosion is promoted not only by slope types of terrain, and high swelling but also by climatic factors. The current state of the region's climate system, which was calculated on the basis of observations from the network of meteorological stations of Roshydromet (Federal Service for Hydrometeorology and Environmental Monitoring), made it possible to define the test area as an area with an average level (1.82-1.86\%) of bioclimatic potential, which is typical for most of the region's territory. The test area belongs to the Second Agro-climatic Region, which covers $70 \%$ of the Oblast territory. In terms of agro-climatic indicators, the test area is classified as a weakly arid humidification zone of a typical forest-steppe subzone with an average moisture index of 0.8-1.0.

Relief and hydrography:

The territory of the farm is located on the south-western spurs of the Central Russian Upland. The territory is characterised by a flat to rolling topography, with a network of large and small ravines and gullies draining the area. The Sitnaya River divides the area of 
the farm into northern and southern parts, which have a common slope towards the river floodplain. The density ratio of the cores that characterise the erosion network of the northern part relative to the southern part is 1.8 (Fig. 1).
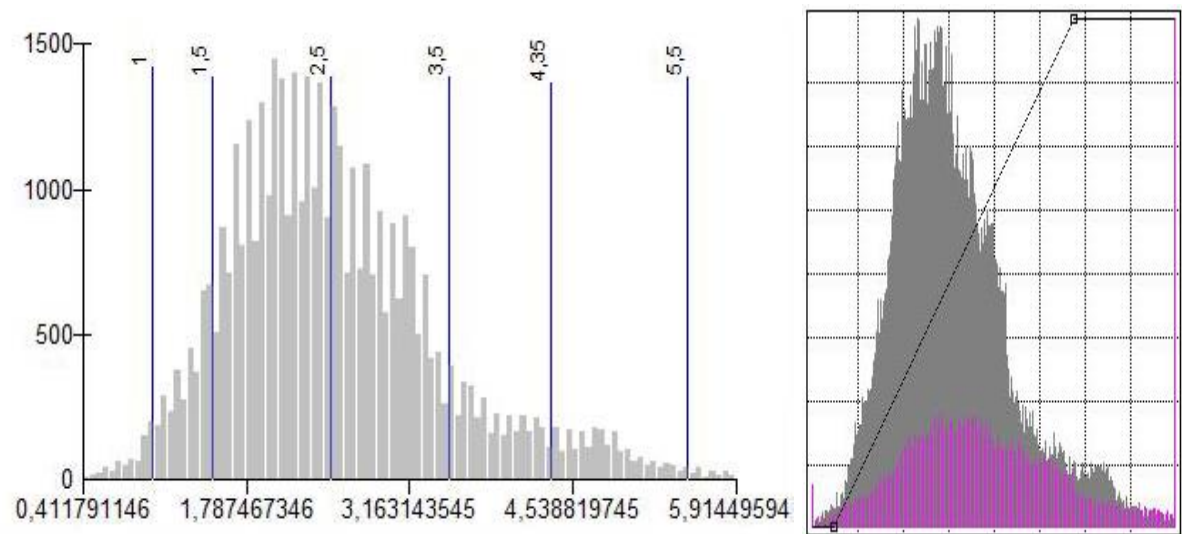

A)
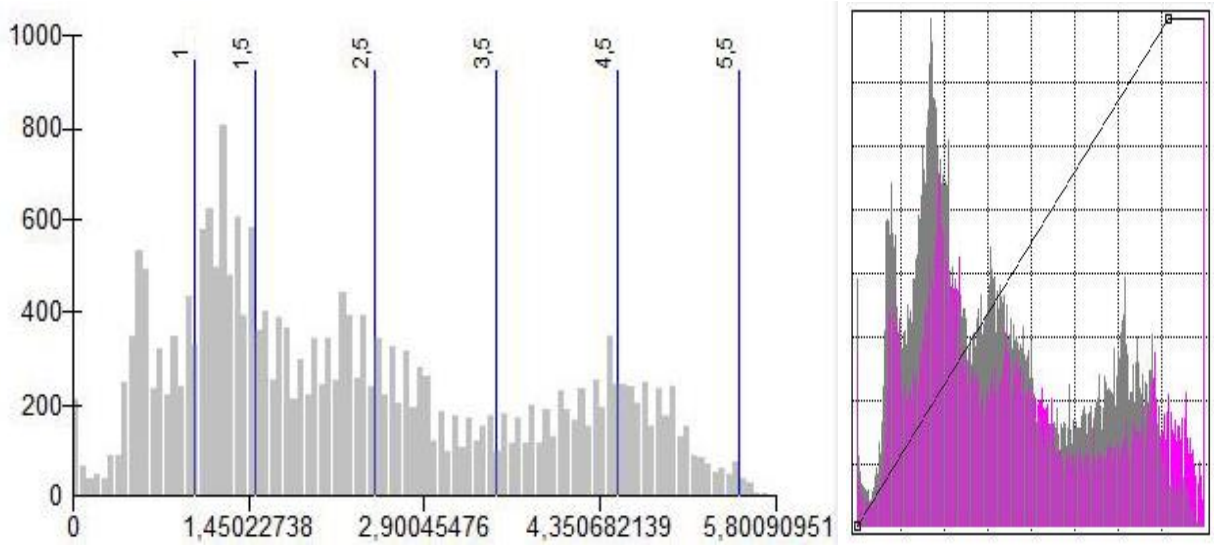

B)

Fig. 1. Histograms of the dismemberment of the territory of JSC "Druzhba": northern part of the economy (A), southern (B)

The northern part of the land use is most dissected, and the gully network is highly developed here. The left bank gullies are directed from south to north, the right bank ones — from north to south; all of them open in the floodplain of the Sitnaya River.

Climate:

The territory of the farm is located in the northern agroclimatic region of the Belgorod Oblast. The climate is moderately continental, with hot summers and moderately warm winters.

The frost-free period lasts for 160-165 days. The average annual precipitation is $600 \mathrm{~mm}$, although it can drop to $500 \mathrm{~mm}$. Both seasonal and year-to-year fluctuations in the total precipitation are noted. Therefore, in general, the climate is characterised by a long frost-free period, sufficient annual precipitation and warmth. The vegetation period lasts for 195 days.

Soils: 
The soil cover on the territory of the farm is quite diverse and consists mainly of ordinary and leached black earths, mainly with clayey loamy composition. On the slopes of the ravines, podzolized, leached, ordinary black earths, typical carbonate, grey and dark grey forest soils have become widespread. In the floodplain of the Sitnaya River floodplain meadow soils have been formed, along the banks of the ravines - soils of ravine slopes of various erosion degrees, and on the bottoms of the ravines, washed soddy soils are common. There are rock outcrops everywhere on the territory of the farm, their total area is 50 ha. On the territory of the farm, the predominant soil types are ordinary $(38.3 \%)$ and leached black earths $(31.9 \%)$; the third place is occupied by ravine black earths $(8.7 \%)$.

Soils on the land use territory are significantly susceptible to water erosion. The area of eroded soil reaches up to 1858 ha, including 1254 ha of arable land, 424 ha of pastures and 50 ha for perennial plantations.

Croplands of the farm are represented mainly by medium $(93.3 \%)$ and low $(6.7 \%)$ humus soils. From the total area of the arable land, low- and medium-eroded soil types account for $20 \%$ and $1.8 \%$, respectively. Soils with a slightly acidic and neutral reaction of the soil solution prevail. On arable soils, there is mainly an average (51\%), low (27\%), and increased $(22.2 \%)$ content of mobile phosphorus.

The availability of exchange potassium in soils is much higher: $53.3 \%$ of soils are characterised by elevated, $36.1 \%$ by high, $10 \%$ by average potassium content.

The forest-steppe soils are in the zone of erosion processes of maximum intensity and the rates of formation are soil formation more than 10 times lower [23] than the average annual rate of erosion losses.

\section{Land fund:}

The land use of the economy is represented by a single massif with a length of $7.5 \mathrm{~km}$ from north to south and $196.5 \mathrm{~km}$ from west to east. The total area of the farm is $7178 \mathrm{ha}$, of which citizens own 918.4 ha of land, legal entities - 85.7 ha of land, the remaining agricultural land is in the state ownership of Belgorod Oblast (86\%). In the land reserves of Druzhba JSC, $79.4 \%$ of lands is agriculturally used areas, $61 \%$ of which is arable lands, $10.2 \%$ is timberlands, $1.1 \%$ is wetlands, and $9.4 \%$ is occupied by transport network, industry, and development.

The slope part of land use (steepness ranges from $8^{\circ}$ to $15^{\circ}$ ) prevails over the upland. The area of land with slopes from $0^{\circ}$ to $3^{\circ}$ is $62.6 \%$ of the territory of the economy, from $3^{\circ}$ to $5^{\circ}-16.2 \%$, from $5^{\circ}$ to $7^{\circ}-10.3 \%$ and more than $7^{\circ}-10.8 \%$. The slopes are mainly straight, less often - concave and convex. On the slopes, there are frequent water galls and slope gullies, which indicates the manifestation of linear erosion. The bottoms of the gullies are well developed, their width fluctuates from 50 to $150 \mathrm{~m}$. The ravines are waterlogged and there are streams running along their watercourse, which together with the Sitnaya and Ilek rivers represent the hydrographic network on the territory of the farm.

The microclimatic conditions and the rate of erosion are influenced by the exposure of slopes. Therefore, this parameter is an essential component of the agroecological assessment of lands [24]. In this case, the share of northern slopes is $21.3 \%$ of the territory, southern $-14 \%$, eastern $-10.4 \%$ and western $-6.7 \%$.

The analysis of the maps obtained thanks to GIS technologies allowed determining the prevalence of transversely convex and longitudinally concave slopes in the study area. And since these types of slopes have different levels of erosion hazard, the maps of slope types create the basis for substantiating the design contour elements of land use planning, considering the transverse profile of the slopes.

The terrain is an active factor in the displacement of soil solids due to erosion. In order to calculate parameters of mechanical migration of the soil material, we carried out determination of the terrain erosive potential. Существуют алгоритмы, которые поэтапно описывают вычисление рельефной функции в GIS [25, 26, 27, 28$].$ 
Previously [11] we presented the methodology, tested on the territory of the Belgorod Oblast, of using tools for automatic calculation of the terrain erosion potential in ArcGIS. The map chart of the terrain erosion potential was constructed based on the weighted average values of the LS model USLE. As a result, the tools of modelling allowed obtaining a spatial distribution of the erosion potential of Druzhba JSC terrain (Fig. 2), which let us assess the activity of water erosion processes and plan measures for soil protection arrangement of the selected test area.

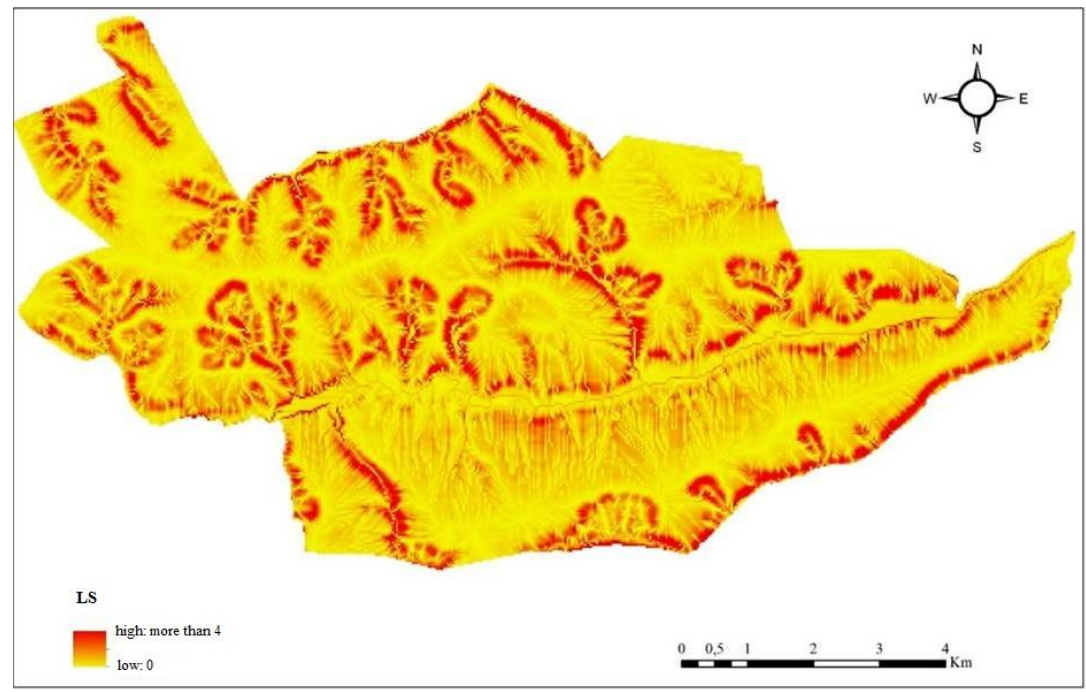

Fig. 2. Raster distribution of the erosion potential of the relief over the territory of JSC "Druzhba" by the values of the topographic factor (LS).

The results of agro-ecological assessment of lands, physical-geographical and economic features of land use determined the possibility of soil protection arrangement of the territory of Druzhba (Fig. 3).

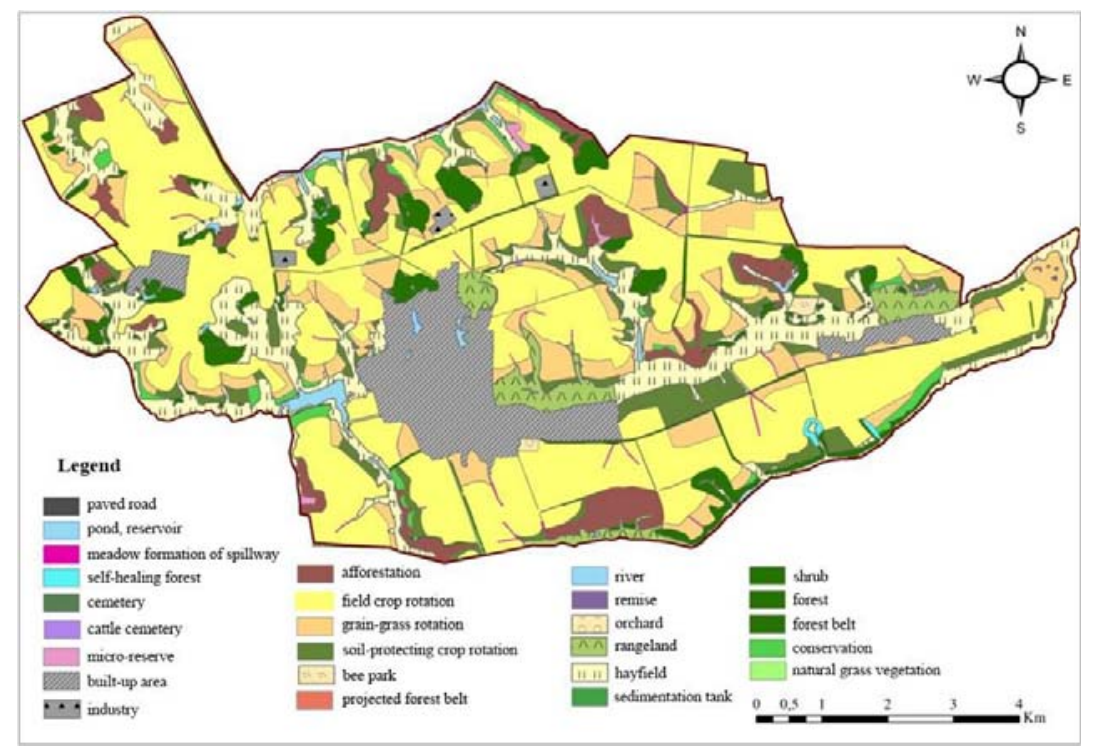

Fig. 3. The project of an adaptive-landscape farming system of JSC "Druzhba". 
The measures for efficient economic use of the territory of Druzhba JSC are based on the following land management actions: organisation of arable lands with the allocation of field, grain-grass, and soil-protective crop rotations, grassing-down of spillways, and conservation of low-productive arable lands, design of field-protective forest range, determination of the type of use of natural forage lands, allocation of places for the implementation of erosion-hazardous agricultural land afforestation, creation of a bee park, clumps of broadleaves and micro-reserves.

Considering the landscape features of the territory, three types of crop rotations have been designed. Field crop rotations with sowing of perennial grasses and break crops are recommended on the arable land with a slope of $0-3^{\circ}$. Grain-grass crop rotations with a share of perennial grasses of about $50 \%$ are designed for erosion-hazardous arable lands with $3-5^{\circ}$ slopes. Conservation crop rotations should be planned for the most dangerous in terms of soil erosion arable lands with more than $5^{\circ}$ slopes. The Project provides for the creation of a field-protective belt with a total area of 4.1 ha as erosion control measures on the arable land. To prevent troughs, a grassing-down of spillways with a total area of 22.4 ha is provided.

Due to the reduction in the number of farms for raising cattle and small ruminants, the concentration of animal husbandry in large complexes, as well as due to the transfer of animal husbandry to tethered technologies, the land under pastures and hayfields is not used efficiently on the territory of a farm. In this regard, the need for pasture plots is decreasing, while the demand for hayfields is growing. The total area of land where the locals used to graze their livestock may be reduced. Thus, on these lands, it is possible to implement activities within the framework of the regional Green Capital project, which aims to increase the forest cover of the territory. Thus, it is recommended to increase the forest cover by $1.5 \%$ by the afforestation of degraded and unproductive agricultural lands. An increase in the ecological stability of the territory ensures an increase in the area of graingrass crop rotations and a reduction in forage lands (by $8 \%$ ), some of which will be transformed into a park with entomophilic crops for beekeeping. When creating a bee park with an area of $10.2 \mathrm{ha}$, it is planned to use $30 \%$ of its area for planting honey trees and shrubs, and $7 \%$ for sowing melliferous crops.

Within the framework of the project, areas for natural regeneration of the vegetation cover were determined as well as the soil use regime for such lands. The renaturation project (on the area of $569 \mathrm{ha}$ ) provides for continuous afforestation $(94.5 \mathrm{ha}$ ), and the determination of land plots for overgrowth with trees and shrubs (10.8 ha), the creation of hunting refuge (1.7 ha) and wildlife reserves (12.6 ha), the grassing-down of runoff dells (22.4 ha), for a bee park (10.2 ha), but mainly the project is associated with increasing the area for soil-protective crop rotations (416.8 ha).

The parameters of the ratio of the main types of lands and monitoring indicators after the implementation of the project are presented in Table 1.

Table 1. Targets and indicators of project implementation

\begin{tabular}{|c|c|c|c|}
\hline \multirow{2}{*}{ Land fund structure } & \multicolumn{2}{|c|}{ Area, ha } & \multirow{2}{*}{ Balance, ha } \\
\cline { 2 - 3 } & $\begin{array}{c}\text { Before the } \\
\text { project }\end{array}$ & $\begin{array}{c}\text { After the } \\
\text { project }\end{array}$ & - \\
\hline Arable land & 4375.2 & 4375.2 & - \\
\hline Field crop rotation & - & 3070.0 & +3070.0 \\
\hline Grain crop rotation & - & 766.8 & +766.8 \\
\hline Conservation crop rotation & - & 416.8 & +416.8 \\
\hline Tinning of spillways & - & 22.4 & +22.4 \\
\hline Land conservation & - & 95.1 & +95.1 \\
\hline Designed forest belts & & 4.1 & +4.1 \\
\hline Gardens & 5.7 & 5.7 & - \\
\hline
\end{tabular}




\begin{tabular}{|c|c|c|c|}
\hline Natural forage lands, including: & 1318.4 & 1213.1 & -105.3 \\
\hline Hayfields & 480.2 & 978.1 & +497.9 \\
\hline Pasture & 831 & 203.3 & -627.7 \\
\hline Natural herbaceous vegetation & 7.2 & 7.2 & - \\
\hline Bee park & - & 10.2 & +10.2 \\
\hline Remises and microreserves & - & 14.3 & +14.3 \\
\hline Forest cover & 730.5 & 835.8 & +105.3 \\
\hline Forest strips existing & 118.3 & 118.3 & - \\
\hline State forest fund & 353.2 & 353.2 & - \\
\hline Shrubs & 28.1 & 28.1 & - \\
\hline Afforestation under the Green & 230.9 & 325.4 & +94.5 \\
\hline Capital project & & & \\
\hline Self-healing forest & - & 10.8 & +10.8 \\
\hline Under water & 76.4 & 76.4 & - \\
\hline Transport land & 26.7 & 26.7 & - \\
\hline Locality & 615.6 & 615.6 & - \\
\hline Industry & 27.2 & 27.2 & - \\
\hline Other & 2.3 & 2.3 & - \\
\hline Total: & 7178.0 & 7178.0 & \\
\hline
\end{tabular}

Ecological effect of the planned soil protection measures was calculated through the coefficient of ecological stability of the territory, which before the design was estimated at 0.42 (unstable), and after the project implementation it was 0.59 (low stable).

\section{Conclusions}

The implementation of projects for agricultural landscapes arrangement based on water and land protection will provide a scientifically based practice of consistent implementation of environmental protection measures, which can provide a higher quality of the environment. Over a short time, it is possible to ensure the stabilisation of degraded soil and environmentally friendly crop production within the framework of the general strategy for transferring agriculture to biological development paths.

The wider implementation of such measures as increasing the areas of perennial grasses, hayfields, while reducing unsystematic grazing near settlements on erosion-hazardous slopes of ravine systems, provides both an increase in the amount of forage produced and an improvement in indicators that characterise the ecological balance of lands. Instead of the widely used moldboard tillage, the gradual introduction of direct seeding methods solves two main problems. Firstly, this is a significant economic benefit from savings on fuels and lubricants, and, secondly, due to the biologisation of agriculture, there will be less pesticide load and lower costs for plant protection products, including herbicides (by $60 \%$ ), insecticides (by $25 \%$ ) and fungicides (by $20 \%$ ).

Thus, by the example of a land use typical for forest-steppe conditions, it is shown that, taking into account available preconditions for the formation of effective land relations and optimisation of forms of economic use of the lands accounting for the design solutions on the efficient use of soil and land resources in agricultural landscapes, the fundamental possibility of the organisation of efficient land use under conditions when the regional share of the land plots under the state custody prevails on the area has been proved.

\section{Acknowledgment}

This work was funded by the Russian Science Foundation, project no. 20-67-46017. 


\section{References}

1. D.S. Nardin, \& S.A. Nardina, Journal of Altai academy of economics and law 1, 58-63 (2020) https://doi.org/10.17513/vaael.939

2. E.A. Stryabkova, A.N. Kogteva, A.M. Kulik, N.A. Gerasimova, Humanities and Social Sciences Reviews 7(5), 782-788 (2019) https://doi.org/10.18510/hssr.2019.7598

3. R. Hălbac-Cotoară-Zamfir, S. Keesstra, Z. Kalantari, Science of the Total Environment, 654, 418-429 (2019) DOI: 10.1016/j.scitotenv.2018.11.160.

4. J. Janoušková, Š. Sobotovičová, Land Use Policy, 82, 30-36 (2019) https://doi.org/10.1016/j.landusepol.2018.11.048

5. N.H. Koroso, J.A. Zevenbergen, M. Lengoiboni, Land Use Policy, 81, 553-564 (2019) https://doi.org/10.1016/j.landusepol.2018.11.026.

6. L. Benedetti, J. Langeveld, A. Comeau, L. Corominas, G. Daigger, C. Martin, et al. Water Science and Technology, 68 (6), 1203-1215 (2013) https://doi.org/10.2166/wst.2013.397

7. X. Fu, M.E. Hopton, X. Wang, H. Goddard, H. Liu, Science of the Total Environment, 689, 1149-1159 (2019) https://doi.org/10.1016/j.scitotenv.2019.06.439.

8. E.V. Orlova, Russian Meteorology and Hydrology, 33(4), 253-258 (2008) https://doi.org/10.3103/S1068373908040092

9. S. Wunder, R. Bodle, Environmental Science and Policy, 92, 46-55 (2019) DOI: 10.1016/j.envsci.2018.09.022

10. R. Jerves-Cobo, L. Benedetti, Y. Amerlinck, K. Lock, C. De Mulder, J. Van Butsel, F. Cisneros, P. Goethals, I. Nopens, Science of the Total Environment 709, 136067 (2020)

11. O.P. Yermolaev, F.N. Lisetskii, O.A. Marinina, Z.A. Buryak, Biosciences Biotechnology Research Asia 12, 145-158 (2015)

12. N.V. Angelopoulos, I.G. Cowx, A.D. Buijse, Environmental Science and Policy, 76, 12-22 (2017)

13. A. Voghera, Land use Policy, 91, 104377 (2020) https://doi.org/10.1016/j.landu sepol.2019.104377.

14. F.N. Lisetskii, A.V. Zemlyakova, E.A. Terekhin, A.G. Naroznyaya, Y.V. Pavlyuk, P.A. Ukrainskii, Z.A. Kirilenko, O.A. Marinina, O.M. Samofalova, Advances in Environmental Biology, 8(10), 536-539 (2014)

15. O.P. Yermolaev, S.S. Mukharamova, K.A. Maltsev, M.A. Ivanov, P.O. Ermolaeva, A.I. Gayazov, V.V. Mozzherin, S.V. Kharchenko, O.A. Marinina, F.N. Lisetskii, IOP Conf. Series: Earth and Environmental Science, 107(1), 012108 (2018) https://doi.org/10.1088/1755-1315/107/1/012108

16. F. Molle, Geoforum, 40 (3), 484-494 (2009)

17. N. Ulugtekin, F.B. Balcik, A.O. Dogru, (...), I.A. Alaton, D. Orhon, Hazardous Substances and Environmental Engineering 44(4), 388-396 (2009)

18. O.A. Marinina, O.P. Yermolaev, K.A. Maltsev, F.N. Lisetskii, Y.V. Pavlyuk, Journal of Engineering and Applied Sciences, 11 (14), 3004-3013 (2016) DOI: $10.3923 /$ jeasci.2016.3004.3013 
19. O.I. Grigoreva, Z.A. Buryak, Research Journal of Pharmaceutical, Biological and Chemical Sciences, 7(1), 2175-2182 (2016)

20. Z. Buryak, O. Grigoreva, A project-based approach to reduce the risk of soil erosion in agricultural landscapes of small river basins using GIS technologies. International Multidisciplinary Scientific GeoConference Surveying Geology and Mining Ecology Management, SGEM, 19(5.2), 19-26 (2019) https://doi.org/10.5593/sgem201 9/5.2/S20.003.

21. F.N. Lisetskii, O.A. Marinina, D.G. Jakuschenko, Research Journal of Pharmaceutical, Biological and Chemical Sciences, 5(6), 1325-1335 (2014)

22. P.A. Ukrainskij, E.A. Terekhin, Ya.V. Pavlyuk, Vestnik Moskovskogo Universiteta, Seriya 5: Geografiya, (1), 82-91 (2017)

23. F.N. Lisetskii, P.V. Goleusov, O.A. Chepelev, Eurasian Soil Science, 46 (5), 491-504 (2013) https://doi.org/10.1134/S1064229313050086

24. V.I. Kiryushin, Eurasian Soil Science 30 (1), 67-73 (1997)

25. R. Hickey, Cartography, 29(1), 1-8 (2000) DOI: 10.1080/00690805.2000.9714334

26. N. Depountis, M. Vidali, K. Kavoura, N. Sabatakakis, WSEAS Transactions on Environment and Development 14, 457-463 (2018)

27. P.R. Anjitha Krishna, R. Lalitha, K. Shanmugasundaram, M. Nagarajan, Journal of the Indian Society of Remote Sensing 47(6), 1031-1039 (2019)

28. S. Lu, B. Liu, Y. Hu, (...), Y. Shi, T. Huang, Catena 187, 104334 (2020) https://doi.org/10.1016/j.catena.2019.104334 